\title{
On the Clumping of Corynebacterium xerosis as Affected by Temperature
}

\author{
By S. O. STANLEY* and A. H. ROSE \\ Department of Microbiology, University of Newcastle upon Tyne
}

(Accepted for publication 1 February 1967)

\begin{abstract}
SUMMARY
Corynebacterium xerosis Strain NCIB 9956 (minimum temperature for growth about $20^{\circ}$ ) formed clumps in cultures or suspensions of bacteria from these cultures, when grown at $30^{\circ}$ and rapidly cooled to $15^{\circ}$ with fast stirring. Electron microscopy showed whole organisms to be connected by an adhesive material. Electron micrographs of thin sections showed that clumps appeared to be formed by single layers of bacteria collecting round gas bubbles. The extent of clumping was greatest around $\mathrm{pH} \mathrm{3,} \mathrm{and} \mathrm{increased} \mathrm{as} \mathrm{the}$ temperature was decreased from $30^{\circ}$ to $15^{\circ}$. Substitution of nitrogen or oxygen for air as gas phase had little effect on the clumping. The clumping ability increased with the age of the culture from the mid-exponential to the late-exponential phase of growth, but thereafter declined. Salts were necessary for clump formation. The relative effects of different monovalent cations and anions depended on the positions of the ions in the Hofmeister series. Incubation of bacteria in buffered solutions of proteolytic enzymes decreased their clumping ability. The extent of clumping also decreased when bacteria were incubated in buffered solutions of guanidine $\mathrm{HCl}(5 \mathrm{M})$, urea $(8 \mathrm{M})$ or in a solution of uranyl nitrate $(10 \mathrm{~mm})$ and $\mathrm{NaCl}(0.1 \mathrm{M})$. Isolated walls of the organism formed clumps when suspensions in phosphate buffer (pH 7.0) were incubated at temperatures between $35^{\circ}$ and $5^{\circ}$ with fast stirring. Pretreatment of walls with trypsin decreased clumping ability. The ability to form clumps when cultures were cooled to $5^{\circ}$ with fast stirring was demonstrated with several but not all of the strains of $C$. xerosis tested.
\end{abstract}

\section{INTRODUCTION}

Strains of Corynebacterium xerosis have much higher minimum temperatures for growth (around $20^{\circ}$ ) than the majority of other mesophilic micro-organisms $\left(5-10^{\circ}\right.$; Bergey's Manual, 1957; Rose \& Evison, 1965). During studies on the biochemical basis of the minimum temperature for growth of a strain of C.xerosis, mid-exponential phase cultures of the bacterium, grown at $30^{\circ}$ in rapidly stirred cultures, were transferred to $15^{\circ}$ with the object of analysing the bacteria after a period of incubation at the subminimum temperature. This shift in incubation temperature caused some of the bacteria in the culture to form clumps. The present paper describes experiments done to discover the basis of this clumping, and also reports on the ability of other corynebacteria and related organisms to form clumps at low temperatures.

\footnotetext{
* Present address: Department of Microbiology, Oregon State University, Corvallis, Oregon, U.S.A.
} 


\section{METHODS}

Organisms. Most of the work described in this paper was done with a strain of Corynebacterium xerosis NCL from the culture collection of this Department (Rose \& Evison, 1965); the strain has been deposited in the National Collection of Industrial Bacteria, and has been granted the accession number NCIB 9956. Several other bacteria were also examined for the ability to aggregate at low temperatures; the sources of these organisms are given in Table 1 . All bacteria were maintained at $30^{\circ}$ on nutrient agar slopes, and were subcultured every $24 \mathrm{hr}$. Stock cultures were preserved in the lyophilized state.

Experimental cultures. The bacteria were grown in a medium (pH 7.4) identical in composition with that described by Rose \& Evison (1965) except that the concentration of $\mathrm{Na}_{2} \mathrm{HPO}_{4} .12 \mathrm{H}_{2} \mathrm{O}$ was $1.5 \mathrm{~g}$./1., and of $\mathrm{KH}_{2} \mathrm{PO}_{4} 0.5 \mathrm{~g}$./l. Portions $(1150 \mathrm{ml}$.) of glucose-free medium were dispensed into 21 . round, flat-bottom flasks, each of which was fitted with two ports, $2 \mathrm{~cm}$. in diameter, to facilitate sampling of the culture. The ports and neck of each flask were plugged with cotton wool. The medium was sterilized by autoclaving at $115^{\circ}$ for $15 \mathrm{~min}$. and, after cooling, was supplemented with $100 \mathrm{ml}$. of sterile glucose solution $(0.25 \mathrm{~g} . / \mathrm{ml}$.). When larger crops of bacteria were required for preparing cell walls, 41 . of medium were similarly dispensed into 51 . round, flat-bottom flasks. In certain experiments, $6 \mathrm{ml}$. cultures were grown in Samco tubes covered with anodized aluminium caps (Oxo Ltd., Queen Street Place, London, E.C. 4; Northam \& Norris, 1951). Inocula were prepared by suspending sufficient organisms from a 24-hr slope culture in $6 \mathrm{ml}$. phosphate buffer $(0.1 \mathrm{M}$; pH 7.0; Gomori, 1955) to give the required concentration. Flasks containing $1250 \mathrm{ml}$. medium were inoculated with $6 \mathrm{ml}$. of a suspension containing the equivalent of $0.11 \mathrm{mg}$. dry-wt bacteria $/ \mathrm{ml}$. Smaller $(6 \mathrm{ml}$.) portions of medium were inoculated with a proportionately smaller volume of this suspension. Larger volumes $(4 \mathrm{l}$.) of medium were inoculated with $9 \mathrm{ml}$. of a suspension containing equiv. $0.60 \mathrm{mg}$. dry-wt bacteria $/ \mathrm{ml}$. Cultures were incubated in individual Perspex baths through which was circulated water at a constant temperature. Unless otherwise stated, the temperature of incubation was $30^{\circ}$. Particular attention was given to the maintenance of the incubation temperature since preliminary experiments indicated that growth of Corynebacterium xerosis NCIB 9956 was very sensitive to small changes in temperature. Larger (41. and $1250 \mathrm{ml}$.) cultures were agitated by using magnetic stirrers (Gallenkamp and Co. Ltd.; model SS 420), and polytetrafiuoroethylene (PTFE)-covered magnets $(4 \mathrm{~cm}$. long in $1250 \mathrm{ml}$. cultures; $6 \mathrm{~cm}$. long in 41 . cultures). After inoculation, the cultures were stirred slowly (about $100 \mathrm{rev}$. of magnet/min.) for $5 \mathrm{hr}$, after which time the rate of stirring was increased to about $1250 \mathrm{rev} . / \mathrm{min}$. The period of slow stirring immediately after inoculation shortened the length of the lag phase of growth. The content of bacteria in cultures was estimated gravimetrically. Triplicate portions of culture, containing about equiv. 3-5 mg. dry-wt bacteria, were filtered through membrane filters (Millipore Filter Corporation, Bedford, Massachusetts, U.S.A.; $25 \mathrm{~mm}$. diam., 0.8 $\mu$ pore size) which had been dried at $100^{\circ}$ to constant weight, and cooled in a desiccator over silica gel. The bacteria on a filter were washed with two portions $(10 \mathrm{ml}$.) of distilled water, and the filter then removed from the holder and dried to constant weight at $100^{\circ}$. Growth of certain cultures was also measured turbidimetrically in glass cells ( $1 \mathrm{~cm}$. light path) in the Hilger 'Spekker' absorptiometer (model H760) 
with neutral green-grey H508 filters and a medium blank. Turbidity readings of C. xerosis NCIB 9956 cultures were related to dry weight of bacteria by using a calibration curve.

Harvesting of organisms. Except when otherwise stated, bacteria were harveste dfrom cultures by centrifugation at $1300 \mathrm{~g}$ for $20 \mathrm{~min}$. at $0^{\circ}$. The supernatant fluid was rejected and the organisms washed twice with ice-cold phosphate buffer $(\mathrm{pH} 7 \cdot 0)$. The organisms were then resuspended in buffer and stored at $4^{\circ}$ until used. Storage of the bacteria at this temperature for up to $96 \mathrm{hr}$ had no measurable effect on their clumping ability.

Measurement of clumping ability. The clumping ability of bacteria was measured in $350 \mathrm{ml}$. conical flasks by using portions $(100 \mathrm{ml}$.) of bacterial culture or suspension which had been diluted, when necessary, to contain equiv. 0.35-0.40 mg. dry-wt bacteria/ml. However, preliminary experiments indicated that measurements of the clumping ability of bacteria from a given batch of organisms did not differ when they were made by using suspensions containing as little as equiv. $0.15 \mathrm{mg}$. dry-wt bacteria/ml. or as much as $0.70 \mathrm{mg} . / \mathrm{ml}$. The culture or suspension contained a PTFE-covered magnet $(4 \mathrm{~cm}$. long). The flasks were incubated in Perspex water baths through which was circulated water at the specified temperature. In most experiments, the temperature of the bath was maintained constant, although it was occasionally decreased during an experiment. The culture or suspension was allowed to equilibrate at the temperature of the bath for $5 \mathrm{~min}$., during which time it was slowly stirred (about 100 rev. of magnet/min.); after this period of equilibration, the stirring rate was increased to $1250 \mathrm{rev}$./min. for $10 \mathrm{~min}$.; this caused considerable aeration in the cultures or suspensions. The extent of clumping in the culture or suspension was then measured by transferring a portion $(5 \mathrm{ml}$.) into a glass cell $(1 \mathrm{~cm}$. light path) and allowing it to stand in the cell holder of the Hilger 'Spekker' absorptiometer for $5 \mathrm{~min}$. at room temperature $\left(18-22^{\circ}\right)$. During this period, any clumps of bacteria present in the culture or suspension rose to the surface. By measuring the turbidity of the underlying fluid, and comparing this with the turbidity of the culture or suspension before clumping occurred, calculations were made of the percentage dry weight of bacteria that had clumped. Except when otherwise stated, there was no further decrease in turbidity when the culture or suspension was allowed to stand in the cell holder for $10 \mathrm{~min}$. This method for measuring the clumping ability of bacteria gave very consistent results with suspensions of organisms from the same culture and tested under the same conditions. There were, however, small variations in the clumping ability of Corynebacterium xerosis NCIB 9956, harvested from different cultures grown at $30^{\circ}$ and at approximately the same stage of growth, and tested under the same conditions of temperature, $\mathrm{pH}$ value and concentration of organisms. The reason for this variation is not known; it may have been due partly to small differences in the age of the culture at the time of harvesting. For this reason, the effects of each environmental factor on clumping were examined by using bacteria from the same culture.

Preparation of cell walls. Cell walls of Corynebacterium xerosis NCIB 9956 were prepared by shaking a suspension of the organisms with glass beads in a cell homogenizer (B. Braun, Melsungen, West Germany; model MSK). Bacteria were harvested from cultures containing about equiv. $0.45 \mathrm{mg}$. dry-wt $/ \mathrm{ml}$., and were washed twice with ice-cold phosphate buffer ( $\mathrm{pH} 7.0$ ). Washed bacteria (equiv. $2.4 \mathrm{~g}$. dry-wt) were suspended in $12 \mathrm{ml}$. phosphate buffer ( $\mathrm{pH} 7.0$ ) and the suspension placed in a 'Duran' Pyrex glass flask (40 ml. capacity with a false bottom) containing $25 \mathrm{ml}$. Ballotini 
glass beads (grade 12). The flask was shaken in the homogenizer at $4000 \mathrm{rev}$./min. for $60 \mathrm{sec}$, during which time the bottle and its contents were cooled with a stream of $\mathrm{CO}_{2}$. The bottle was then taken off the homogenizer, and the glass beads removed from the suspension by filtration through a sintered glass filter (Baird and Tatlock Ltd., London; porosity 1). Unbroken organisms were removed from the filtrate by centrifugation at $1300 \mathrm{~g}$ for $45 \mathrm{~min}$. at $0^{\circ}$. Cell walls were separated from the supernatant fluid by centrifugation at $12,500 \mathrm{~g}$ for $30 \mathrm{~min}$. at $2-5^{\circ}$ in an M.S.E. High Speed ' 18 ' refrigerated centrifuge. The walls were washed twice with phosphate buffer at $2-5^{\circ}$ and then with distilled water also at $2-5^{\circ}$ until the extinction reading of the washings, at $260 \mathrm{~m} \mu$ in a cuvette of $1 \mathrm{~cm}$. light path, was not greater than 0.03 . The cell walls were then suspended in distilled water and stored at $0^{\circ}$ for short periods, or freeze-dried. The purity of the isolated cell walls was confirmed by examining shadowed preparations in the electron microscope.

Light microscopy. Drops of liquid cultures of Corynebacterium xerosis NCIB 9956 were put on glass slides, covered with cover slips, and examined with a Zeiss Photomicroscope; the no. 22 or 40 objective was used, and the illumination source was a high intensity lamp. Photographs were taken with Ilford HP 3 film. The total microscope magnification was $\times 64$.

Electron microscopy. Bacteria which were to be examined as shadowed preparations in the electron microscope were harvested by filtering a portion of culture through a Millipore membrane filter ( $25 \mathrm{~mm}$. diam.; $0.8 \mu$ pore size). The organisms on the filter were washed twice with phosphate buffer $(\mathrm{pH} \mathrm{7 \cdot 0)}$ and once with distilled water. They were then suspended in water, and one drop of the diluted suspension (containing less than equiv. $0.001 \mathrm{mg}$. dry-wt $/ \mathrm{ml}$.) was placed on a carbon-coated copper grid (3.05/3.10 mm.; 200-mesh; Smethurst High-Light Ltd., Bolton, Lancs.) laid on an aluminium block surrounded with a mixture of ethanol $(95 \%, v / v$ in water) and solid carbon dioxide. Drops of suspensions of washed cell walls (containing equiv. $0.001 \mathrm{mg}$. dry-wt/ml.) were similarly placed on the grids. The drops of suspension quickly froze on the grids, which were then freeze-dried. The grids were shadowed at an angle of $\cot ^{-1} 3$ with gold + palladium before being examined with the electron microscope. Whole-organism preparations were examined in the Akashi Tronscope (model TRS 50) with a $50 \mu$ objective and an accelerating voltage of $50 \mathrm{kV}$; photographs were taken at an instrument magnification of $\times 10,000$. Cell wall preparations were examined in an EM6 electron microscope (Associated Electrical Industries Ltd., Harlow, Essex) with a $50 \mu$ objective and an accelerating voltage of $75 \mathrm{kV}$; photographs were taken at an instrument magnification of $\times 10,000$.

For the examination of carbon replicas of bacteria in the electron microscope, a drop of suspension of organisms (containing equiv. $0.001 \mathrm{mg}$. dry-wt/ml.) was freezedried on a Formvar-coated copper grid. The organisms were then coated with carbon and the Formvar removed by solution in chloroform. The coated bacteria were then treated with a solution of $\mathrm{KMnO}_{4}$ in sulphuric acid according to the method of Bradley \& Williams (1957). The carbon replicas were shadowed with gold + palladium at an angle of $\cot ^{-1} 3$, and examined in the EM6 electron microscope (50 $\mu$ objective aperture and an accelerating voltage of $75 \mathrm{kV}$ ). Photographs were taken at an instrument magnification of $\times 10,000$.

Bacteria were fixed for the preparation of thin sections by adding $6 \mathrm{ml}$. glutaraldehyde solution $(25 \%$, w/v) to $94 \mathrm{ml}$. culture containing the equivalent of about $25 \mathrm{mg}$. 
dry-wt bacteria. The suspension was maintained at $30^{\circ}$ for $15 \mathrm{~min}$. and then cooled to $5^{\circ}$ for $15 \mathrm{~min}$. It was then centrifuged and the bacteria washed twice with cold $\left(5^{\circ}\right)$ phosphate buffer ( $\mathrm{pH} 7.0$ ) after which they were fixed for $2 \mathrm{hr}$ at $0^{\circ}$ in buffered osmium tetroxide $(0.5 \%, \mathrm{w} / \mathrm{v}$, in phosphate buffer, $\mathrm{pH} 7 \cdot 0)$. The suspension was again centrifuged, and the bacteria washed twice in phosphate buffer ( $\mathrm{pH} \mathrm{7.0)}$ and then dehydrated by suspending in graded concentrations of methanol in water $(50,75,95 \%, \mathrm{v} / \mathrm{v}$; $5 \mathrm{~min}$. in each) followed by two periods each of $5 \mathrm{~min}$. in absolute methanol. The dehydrated organisms were then suspended for $30 \mathrm{~min}$. in $3 \mathrm{ml}$. of a solution of uranyl nitrate $(30 \%, w / v$, in absolute methanol). The stained organisms were centrifuged and washed three times with absolute methanol. They were finally dehydrated by suspending in $3 \mathrm{ml}$. 1,2-epoxypropane for $15 \mathrm{~min}$., followed by suspension in a further $3 \mathrm{ml}$. for $15 \mathrm{~min}$. The organisms were then suspended in a mixture $(1+1$, by vol.) of Araldite mixture+1,2-epoxypropane for $1 \mathrm{hr}$. Araldite mixture was prepared by mixing Araldite CY $212(20 \mathrm{ml}$.), resin HY 964 (20 ml.), benzene dimethylamine (accelerator BDMA; $0.6 \mathrm{ml}$.), and dibutyl phthalate $(2 \mathrm{ml}$.). The organisms were centrifuged from the Araldite+epoxypropane and resuspended in Araldite mixture alone in gelatin capsules (No. 0; Eli Lilly and Co. Ltd., Basingstoke, England); the Araldite was polymerized by incubation at $60^{\circ}$ for $48 \mathrm{hr}$. Sections were cut with a Huxley ultramicrotome (manufactured in the Engineering Laboratories, Cambridge University) with glass knives. Only sections showing silver or gold interference patterns (60-100 m $\mu$ thick) were examined. Sections were examined in the Akashi Tronscope (model TRS-50) with an objective aperture of $50 \mu$ and an accelerating voltage of $50 \mathrm{kV}$; photographs were taken at an instrument magnification of $\times 15,000$.

Thin sections of clumps of bacteria were prepared by embedding stained preparations in methacrylate. This technique was used since it gave greater contrast in the material than the technique used for examining sections of individual bacteria. Fixing and staining of the clumps were done as described for individual bacteria. After washing three times in absolute methanol, the dehydrated material was suspended for $15 \mathrm{~min}$. in a mixture $(1+1)$ of absolute methanol +monomer mixture ( $n$-butyl and methyl methacryates, $6+1$, by vol.), followed by suspension for $3 \mathrm{hr}$ in pure monomer mixture. Finally, the clumps were suspended for $30 \mathrm{~min}$. in a mixture of the monomers $(6+1$, by vol.) which had been partially polymerized with benzoyl peroxide $(2 \%$, w/v) as described by Mercer \& Birbeck (1961). The clumps were then centrifuged, and small pieces of the pellet transferred to gelatin capsules (no. 0 ) containing the methacrylate mixture. Polymerization was done by maintaining the capsule at $60^{\circ}$ for $48 \mathrm{hr}$. Sections were cut with a Huxley ultramicrotome using glass knives. Sections (60-100 m $\mu$ thick) were examined in the Akashi Tronscope (model TRS-50) with an objective aperture of $50 \mu$ and an accelerating voltage of $50 \mathrm{kV}$. Photographs were taken at an instrument magnification of $\times 2500$.

Chemicals. All chemicals and reagents used were of the highest purity available commercially. Where possible, AnalaR chemicals were used. Casamino acids (technical) was obtained from Difco Laboratories Inc., Detroit, Michigan, U.S.A. Hyaluronidase (ex. bovine testes), lipase (ex. wheat germ), lysozyme chloride (ex. egg white), pancreatin (ex. hog pancreas), papain (ex. papaya latex), pepsin (ex. hog stomach mucosa; crystalline), trypsin (ex. bovine pancreas; recrystallized twice), vitamins and glutaraldehyde solution $(25 \%$, w/v, in water) were obtained from Koch-Light Laboratories Ltd., Colnbrook, Buckinghamshire. Amino acids and reagents used for reacting with 
proteins were supplied by British Drug Houses, Ltd., Poole, Dorset. Araldite CY 212 and resin HY964 were obtained from Ciba (A.R.L.) Ltd., Duxford, Cambridge. Benzene dimethylamine (accelerator BDMA) was obtained from Shell Chemicals Ltd., 15-17, Great Marlborough Street, London, W. 1. Nystatin ('Mycostatin') was purchased from E. R. Squibb and Sons, New Brunswick, New Jersey, U.S.A.

\section{RESULTS}

Ability of coryneform bacteria to form clumps at $5^{\circ}$

Clumping at temperatures below the minimum for growth was first observed in cultures of Corynebacterium xerosis NCIB 9956 described by Rose \& Evison (1965). It was decided to examine the ability of related bacteria, particularly other coryneform

Table 1. Ability of various coryneform bacteria to form clumps at $5^{\circ}$, in relation to the minimum temperatures for growth

\begin{tabular}{|c|c|c|c|}
\hline Species & Strain & $\begin{array}{l}\text { Ability to } \\
\text { form } \\
\text { clumps at } \\
5^{\circ}\end{array}$ & $\begin{array}{l}\text { Approx. min. } \\
\text { temp. for } \\
\text { growth }\left(^{\circ}\right)\end{array}$ \\
\hline Corynebacterium aquaticum & NCIB 9460 & + & $5-10$ \\
\hline C. manihot & NCIB 9097 & - & $5-10$ \\
\hline C. mediolanum & NCIB 7206 & + & $10-15$ \\
\hline C. ovis & Laboratory strain & + & $20-25$ \\
\hline C. rubrum & NCIB 9433 & - & $5-10$ \\
\hline C. xerosis & $\begin{array}{l}\text { NCIB } 9956 \text { (Rose \& } \\
\text { Evison, 1965) }\end{array}$ & + & $15-20$ \\
\hline C. xerosis & ATCC 373 & + & $10-15$ \\
\hline C. xerosis & ATCC 9061 & + & $15-20$ \\
\hline C. xerosis & ATCC 9755 & - & $20-25$ \\
\hline C. xerosis & NCTC 7243 & + & \\
\hline Corynebacterium sp. & NCMB 12 & - & $5-10$ \\
\hline Corynebacterium sp. & NCMB 16 & - & $5-10$ \\
\hline Corynebacterium sp. & NCMB 31 & + & $5-10$ \\
\hline Coryneform & NCIB 8179 & - & $5-10$ \\
\hline Coryneform & NCIB 8180 & - & $0-5$ \\
\hline Coryneform & NCIB 8181 & - & $5-10$ \\
\hline Microbacterium flavum & NCIB 8707 & - & $10-15$ \\
\hline M. lacticum & NCIB 8540 & - & $15-20$ \\
\hline M. lacticum & NCIB 8541 & - & $5-10$ \\
\hline
\end{tabular}

organisms, to form clumps at low temperatures, and to discover whether this ability was found only in bacteria with high minimum temperatures for growth. The results of this survey are given in Table 1. Two of the bacteria examined, namely C. xerosis ATCC 7091 and Corynebacterium sp. NCMB 8, were unable to grow in the medium used. C. xerosis ATCC 7711 grew in the form of aggregates in cultures incubated at $30^{\circ}$, which made it difficult to detect the formation of clumps at low temperatures. All of the other bacteria examined grew as discrete organisms at $30^{\circ}$. Several of the corynebacteria formed clumps when cultures were rapidly stirred and cooled to $5^{\circ}$. However, not all of these bacteria had high minimum temperatures for growth. 
Microscopic examination of clumps formed by Corynebacterium xerosis NCIB 9956

Attempts to obtain photomicrographs of intermediate stages in clump formation, during the cooling of cultures of Corynebacterium xerosis NCIB 9956 from $30^{\circ}$ to $15^{\circ}$ with fast stirring, were unsuccessful; this indicated that the formation of clumps from discrete bacteria occurred rapidly. A photomicrograph of a clump formed in a culture cooled to $15^{\circ}$ with fast stirring is shown in Pl. 1, fig. 1. Plate 1, fig. 2, is an electron micrograph of bacteria that had been freeze-dried on the electron microscope grid and then shadowed. It shows bacteria connected by presumably adhesive material which does not appear to be localized but to be distributed over the bacterial surface. A carbon replica of $C$. xerosis NCIB 9956 that had been freeze-dried on the electron microscope grid is shown in Pl. 1, fig. 3. The surfaces of the bacteria are seen to be covered by wart-like lumps. An electron micrograph of a thin section of a clump of $C$. xerosis NCIB 9956 is shown in P1. 1, fig. 4. Each clump was hollow and appeared to have been formed by a single layer of bacteria collecting round a gas bubble. The ability of the bacteria in the clumps to remain at least partly in contact after preparation of the material for electron microscopy testified to the mechanical strength of the adhesive material. Plate 1 , fig. 5 , is an electron micrograph of a thin section through bacteria stained with uranyl nitrate, showing patches of electron-dense material on the surfaces of the bacteria.

\section{Effect of environmental factors on clumping of Corynebacterium xerosis NCIB 9956}

Hydrogen-ion concentration. Since the clumping of Corynebacterium xerosis NCIB 9956 involved contact and adhesion at the surface of the organisms, it seemed likely that the $\mathrm{pH}$ value of the suspending fluid might affect the degree of clumping. Figure 1 shows that, at $15^{\circ}$, the clumping ability was greatest when the bacteria were suspended in buffer at pH 3.0. Between $\mathrm{pH} 3$ and 5, there was a decline in the percentage of bacteria that clumped, but clumping ability was little affected by $\mathrm{pH}$ values between 5 and 10 .

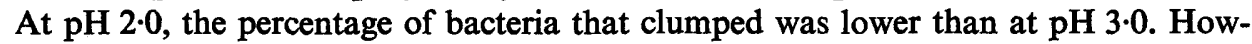
ever, when the suspensions of bacteria in buffer at $\mathrm{pH} 2.0$ were stood in the absorptiometer cell holder for $10 \mathrm{~min}$. instead of $5 \mathrm{~min}$., the turbidity of the suspension decreased further with the result that the extent of clumping then appeared greater than at $\mathrm{pH} \mathrm{3.0.} \mathrm{This} \mathrm{longer} \mathrm{period} \mathrm{of} \mathrm{standing} \mathrm{had} \mathrm{no} \mathrm{effect} \mathrm{on} \mathrm{the} \mathrm{percentage} \mathrm{of} \mathrm{bacteria}$ clumping in buffers at or above $\mathrm{pH} 3.0$. The clumping ability at several $\mathrm{pH}$ values was examined using two different buffering systems, and was shown not to be affected by the chemical composition of the buffers at the concentrations used.

Temperature. The clumping ability of bacteria harvested from exponential-phase cultures and suspended in buffer increased as the temperature of the suspension was decreased below $30^{\circ}$. The extent of clumping at any one temperature depended on the $\mathrm{pH}$ value of the buffer (Fig. 2). At pH 7.0, clump formation was not measurable at $30^{\circ}$, but at $\mathrm{pH} 3.0$ it was appreciable at $40^{\circ}$. The shapes of the Arrhenius curves at $\mathrm{pH} 7.0$ and 3.0 were similar over the range $25^{\circ}-10^{\circ}$ but, at temperatures above $30^{\circ}$, the pH 3.0 curve deviated markedly from that for suspensions at $\mathrm{pH} 7.0$. Bacteria harvested from late exponential-phase cultures formed a few clumps at $30^{\circ}$ in $\mathrm{pH} 7.0$ buffer (see below). No differences could be detected in the clumping ability of bacteria grown at $35^{\circ}$ or $40^{\circ}$ as compared with bacteria grown at $30^{\circ}$, when measured under the same conditions. 
Nature of gas phase. Substitution of nitrogen or oxygen for air as the gas phase had little effect on the clumping ability of bacteria at $15^{\circ}$ (Table 2). However, when hydrogen was used as the gas phase, there was a decrease in the clumping ability.

Age of culture. The clumping ability of the bacteria increased with the age of the culture from the mid-exponential to the late-exponential phases of growth, but declined as the culture entered the stationary phase of growth (Fig. 3). The difficulties

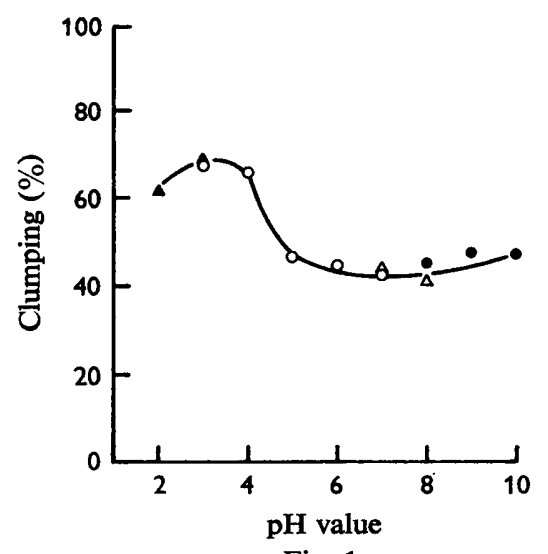

Fig. 1

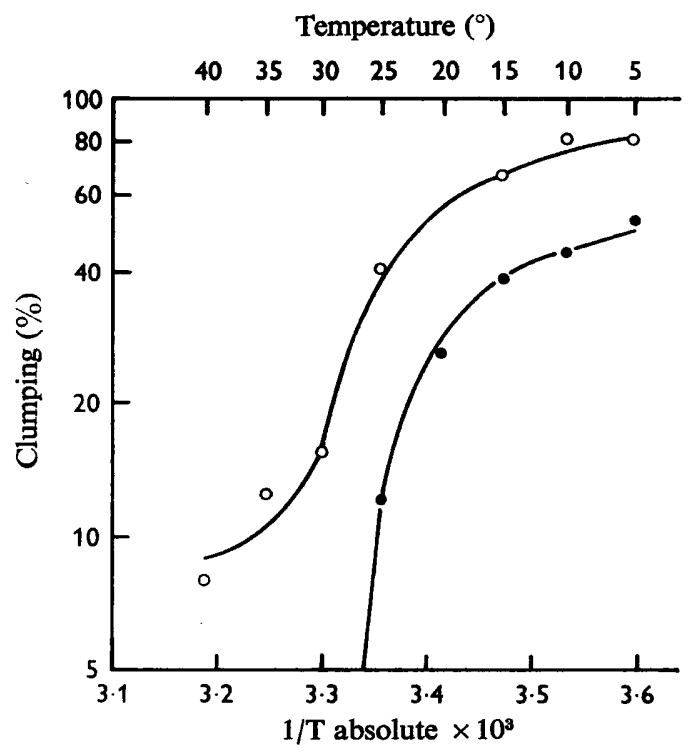

Fig. 2

Fig. 1. Effect of pH value on clumping of Corynebacterium xerosis NCIB 9956. The buffering systems used were $\mathrm{HCl}+\mathrm{KCl}\left(\Delta ;\right.$ Bower \& Bates, 1955), citric acid $+\mathrm{Na}_{2} \mathrm{HPO}_{4}(\mathrm{O}$; Mcllvaine, 1921), $\mathrm{Na}_{2} \mathrm{HPO}_{4}+\mathrm{NaH}_{2} \mathrm{PO}_{4}(\triangle$; Gomori, 1955), and borate $+\mathrm{KCl}+\mathrm{NaOH}$ (๑) Bower \& Bates, 1955). Bacteria were harvested from cultures containing equiv. 0.2$0.3 \mathrm{mg}$. dry-wt bacteria/ml. The extent of clumping was measured as described in Methods.

Fig. 2. Arrhenius plots for the clumping of Corynebacterium xerosis NCIB 9956 at pH 3.0 (O; $\mathrm{HCl}+\mathrm{KCl}$; Bower \& Bates, 1955) and pH 7.0 (O; $\mathrm{Na}_{2} \mathrm{HPO}_{4}+\mathrm{NaH}_{2} \mathrm{PO}_{4} ;$ Gomori, 1955). Bacteria were harvested from cultures containing equiv. $0 \cdot 2-0.3 \mathrm{mg}$. dry-wt bacteria/ml. The extent of clumping at the different temperatures was then measured.

of harvesting bacteria from very early exponential-phase cultures prevented the examination of the clumping ability of these bacteria. Bacteria from mid exponentialphase cultures did not form clumps at $30^{\circ}$ in $\mathrm{pH} 7.0$ buffer, but organisms from late exponential-phase cultures did so to a small extent (less than $10 \%$ ).

Salts. Bacteria did not clump in distilled water at $15^{\circ}$ when the suspension was rapidly stirred, but when salts were present clumps formed. In the presence of $\mathrm{NaCl}$, clump formation was greatest in solutions with an ionic strength of about $0 \cdot 10$ (Fig. 4). An examination of the effects of different monovalent cations and anions showed that these effects could be correlated with the positions of the ions in the Hofmeister or lyotropic series (Young, 1963; Table 3). Divalent $\left(\mathrm{Mg}^{2+}\right)$ and trivalent $\left(\mathrm{Fe}^{3+}\right)$ ions were also effective. 


\title{
Table 2. Effect of different gas phases on the clumping ability of Corynebacterium xerosis NCIB 9956 at $15^{\circ}$
}

\begin{abstract}
Bacteria were harvested from cultures grown at $30^{\circ}$ and containing equiv. $0 \cdot 2-0 \cdot 3 \mathrm{mg}$. dry-wt bacteria/ml. The bacteria were washed twice in phosphate buffer (pH 7) and resuspended in this buffer to a concentration of equiv. $35 \mathrm{mg}$. dry-wt/ml. Phosphate buffer ( $99 \mathrm{ml}$; ; pH 7.0) was placed in a $350 \mathrm{ml}$. conical flask, containing a PTFE-covered magnet and fitted with a rubber bung through which was passed a gas sparger and an outlet tube. The flask was placed in the water bath at $15^{\circ}$, and the gas from a cylinder was then blown through the buffer for $15 \mathrm{~min}$. during which time the buffer was stirred slowly. The sparging jet was then raised to about $1 \mathrm{~cm}$. above the level of liquid in the flask, and $1 \mathrm{ml}$. of the suspension of bacteria added to the buffer. The clumping ability of the bacteria was then determined as described under Methods. Gas was flushed into the flask while the suspension
\end{abstract} was rapidly stirred.

$\begin{array}{lc} & \begin{array}{c}\text { Extent of } \\ \text { clumping at } 15^{\circ}\end{array} \\ \text { Nature of gas } & (\%)\end{array}$

Table 3. Effect of salts on the clumping ability of Corynebacterium xerosis NCIB 9956 at $15^{\circ}$

Bacteria were harvested from cultures grown at $30^{\circ}$ and containing equiv. $0 \cdot 2-0 \cdot 3 \mathrm{mg}$. drywt bacteria $/ \mathrm{ml}$. The bacteria were washed twice in $\mathrm{pH} 7.0$ phosphate buffer and twice in distilled water, and resuspended in the salt solution to a concentration equiv. $0.35 \mathrm{mg}$. dry$\mathrm{wt} / \mathrm{ml}$. The suspensions were cooled at $15^{\circ}$ with slow stirring, and the extent of clumping determined. Each ion was tested at an ionic strength of $0 \cdot 10$. Cations were present as chlorides; anions as potassium salts.

\begin{tabular}{|c|c|}
\hline Ion & $\begin{array}{l}\text { Extent of } \\
\text { clumping at } 15^{\circ} \\
(\%)\end{array}$ \\
\hline Cations: $\begin{aligned} & \mathrm{K}^{+} \\
& \mathbf{N a}^{+} \\
& \mathbf{L i}^{+}\end{aligned}$ & $\begin{array}{l}47 \cdot 8 \\
40 \cdot 7 \\
36 \cdot 3\end{array}$ \\
\hline Anions: $\begin{aligned} \mathrm{Cl}^{-} \\
\\
\mathrm{NO}_{3}^{-} \\
\mathrm{I}^{-} \\
\mathrm{CNS}^{-}\end{aligned}$ & $\begin{array}{l}41 \cdot 7 \\
42 \cdot 5 \\
46 \cdot 2 \\
47 \cdot 8\end{array}$ \\
\hline
\end{tabular}

\section{Effect of different treatments on the clumping of Corynebacterium xerosis NCIB 9956}

Information about the chemical nature of the cell-surface components responsible for the increased clumping of the corynebacterium at low temperatures was sought by examining ability to form clumps after the organisms had been subjected to various treatments. Boiling a suspension of the bacteria in phosphate buffer $(\mathrm{pH} \mathrm{7.0)}$ ), or repeated freezing and thawing of a suspension in the same buffer, had no detectable effect on ability to form clumps at $15^{\circ}$. Other treatments which did not affect ability to clump at $15^{\circ}$ included extraction with a hot mixture of chloroform + methanol ( $3+1$ by vol.; Kates, Adams \& Martin, 1964), incubation for $15 \mathrm{~min}$. in buffer (pH 7.0) containing 0.1 M-sodium periodate (Hotchkiss, 1948) or $0.25 \mathrm{mg}$. nystatin $/ \mathrm{ml}$. (Lampen, Arnow, Borowska \& Laskin, 1962). However, the clumping ability of bacteria suspended at $15^{\circ}$ in $\mathrm{NaCl}(0 \cdot 1 \mathrm{M})$ containing uranyl nitrate $(10 \mathrm{~mm})$ quickly 
decreased, although some of these bacteria were able to clump even after incubation in the solution for $60 \mathrm{~min}$. (Table 4). Bacteria suspended in a solution containing only uranyl nitrate $(10 \mathrm{mM})$ did not form clumps under these conditions.

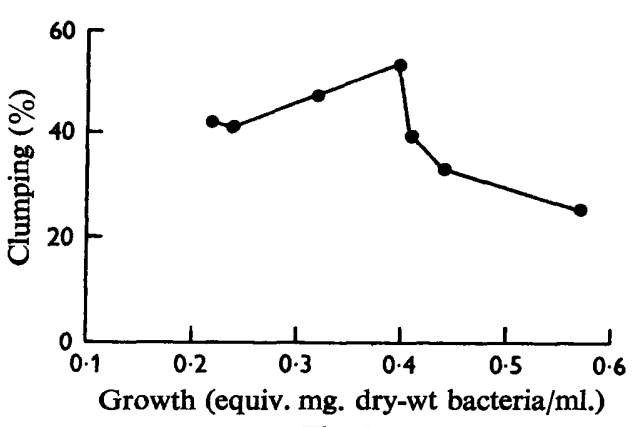

Fig. 3

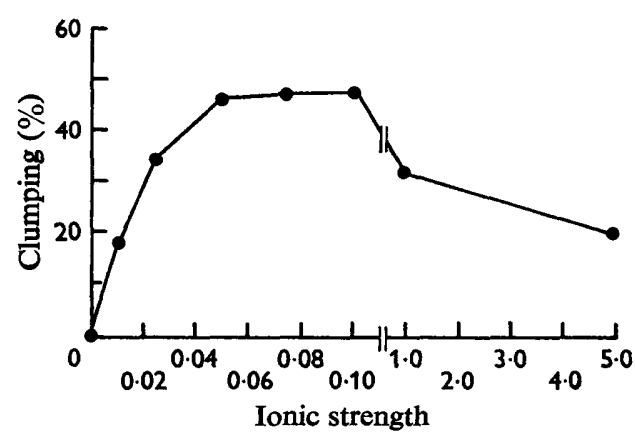

Fig. 4

Fig. 3. Effect of culture age on clumping of Corynebacterium xerosis $\mathrm{NCrB} 9956$ at $15^{\circ}$ and $\mathrm{pH} 7 \cdot 0$. Observations were made during the late-exponential phase (equiv. $0 \cdot 2-0 \cdot 4 \mathrm{mg}$. dry-wt/ $\mathrm{ml}$.) and early stationary phase (equiv. $0.4-0.55 \mathrm{mg}$. dry-wt $/ \mathrm{ml}$.) of cultures. Bacteria were harvested from cultures grown at $30^{\circ}$ by filtration through a membrane filter, and were washed on the filter with phosphate buffer ( $\mathrm{pH} 7 \cdot 0$ ). The extent of clumping was then measured.

Fig. 4. Effect of $\mathrm{NaCl}$ concentration on clumping of Corynebacterium xerosis $\mathrm{NCIB} 9956$ at $15^{\circ}$. Bacteria were harvested from cultures grown at $30^{\circ}$ and containing equiv. $0 \cdot 2-0 \cdot 3 \mathrm{mg}$. drywt bacteria $/ \mathrm{ml}$. The extent of clumping was then measured.

\section{Table 4. Effect of uranyl nitrate on the clumping ability of Corynebacterium xerosis NCIB 9956 at $15^{\circ}$}

Bacteria were harvested from cultures grown at $30^{\circ}$ and containing equiv. $0 \cdot 2-0 \cdot 3 \mathrm{mg}$. drywt. bacteria $/ \mathrm{ml}$. The bacteria were washed twice in $\mathrm{pH} 7.0$ phosphate buffer and twice in distilled water, and resuspended at $15^{\circ}$ in $\mathrm{NaCl}(0 \cdot 1 \mathrm{M})$ containing uranyl nitrate $(10 \mathrm{mM})$ to a concentration equiv. of $0.35 \mathrm{mg}$. dry-wt $/ \mathrm{ml}$. The suspension was stirred slowly for the times indicated and the clumping ability of the bacteria then determined.

$\begin{array}{cc}\begin{array}{c}\text { Duration of incubation in } \\ \text { NaCl-uranyl nitrate } \\ \text { solution at } 15^{\circ}\end{array} & \begin{array}{c}\text { Extent of } \\ \text { clumping at }\end{array} \\ \text { (min.) } & 15^{\circ} \\ (\%) & 63 \cdot 5 \\ 5 & 40 \cdot 5 \\ 15 & 28 \cdot 0 \\ 30 & 28 \cdot 0 \\ 45 & 28.0 \\ 60 & 30.0\end{array}$

Incubation of a suspension of bacteria at $37^{\circ}$ in phosphate buffer (pH 7.0) containing individual enzymes $(500 \mu \mathrm{g} . / \mathrm{ml}$.) was also studied. Incubation in solutions of hyaluronidase, lipase, lysozyme chloride or phospholipase $D$ had no measurable effect on ability to clump at $15^{\circ}$. Incubation in solutions of proteolytic enzymes had some effect (Table 5), and the ability to form clumps was completely removed by suspending bacteria for $1 \mathrm{hr}$ in $\mathrm{pH} \mathrm{7.0} \mathrm{buffer} \mathrm{containing} \mathrm{papain}(500 \mu \mathrm{g} . / \mathrm{ml}$.). Incubation of suspensions of bacteria in $\mathrm{pH} 7.0 \mathrm{buffer}$ containing trypsin $(500 \mu \mathrm{g} . / \mathrm{ml}$. $)$ led to the disappearance of much of the adhesive material that surrounded shadowed preparations of bacteria on electron micrographs (P1. 1, fig. 2). 
Experiments were also done with reagents that react with different groups in proteins to discover which groups in the cell-surface protein were involved in clump formation. Because of the need to use relatively mild conditions only a few reagents could be tested. As shown in Table 6, only guanidine- $\mathrm{HCl}$ and urea of the reagents tested had an effect on the clumping ability of the bacteria.

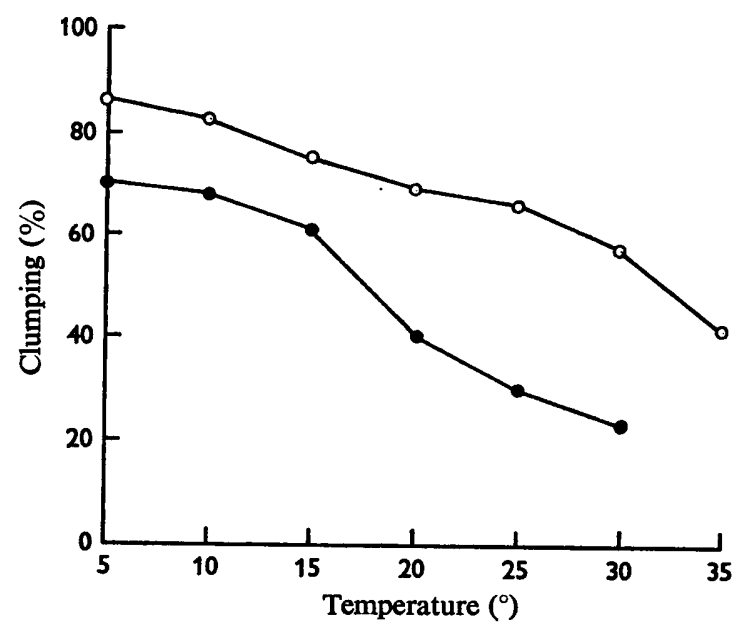

Fig. 5. Effect of temperature on clumping of isolated cell walls of Corynebacterium xerosis NCIB 9956. Cell walls were prepared as described in Methods. $\rightarrow$ indicates the response of walls after treatment with trypsin $(500 \mu \mathrm{g} . / \mathrm{ml}$.) in $\mathrm{pH} 7.0$ phosphate buffer for $4 \mathrm{hr}$, as described in Table 5; $O$ indicates the response of untreated walls. The extent of clumping was measured as described in Methods, except that the wall suspensions were stood for $20 \mathrm{~min}$. in the absorptiometer cell holder.

Table 5. Effect of proteolytic enzymes on the ability of Corynebacterium xerosis $\mathrm{NCIB} 9956$ to form clumps at $15^{\circ}$

Bacteria were harvested from cultures grown at $30^{\circ}$ and containing equiv. 0.2-0.3 mg. drywt. bacteria $/ \mathrm{ml}$. The bacteria were washed and resuspended to a concentration equiv. $5 \mathrm{mg}$. dry-wt $/ \mathrm{ml}$. in buffer $(20 \mathrm{ml}$ ) at pH 2.3 ( $\mathrm{HCl}+\mathrm{KCl}$; Bower \& Bates, 1955), pH 4.5 (acetic acid sodium acetate; Walpole, 1914), or pH 7.0 (phosphate $0.1 \mathrm{M}$; Gomori, 1955) in the presence and absence of the proteolytic enzyme $(500 \mu \mathrm{g} . / \mathrm{ml}$.). The suspensions were shaken at 176 rotations/min. in a New Brunswick Gyrotary shaker-incubator (model G-25) for $1 \mathrm{hr}$. The suspensions were then passed through a membrane filter (Oxoid), the bacteria washed with $20 \mathrm{ml}$. phosphate buffer $(\mathrm{pH} \mathrm{7.0})$ at $37^{\circ}$, and resuspended in phosphate buffer $(\mathrm{pH} \mathrm{7.0}$; $100 \mathrm{ml}$.) to a concentration equiv. $0.38 \mathrm{mg}$. dry-wt bacteria $/ \mathrm{ml}$. The extent of clumping at $15^{\circ}$ was then measured.

\begin{tabular}{lcc}
\multicolumn{1}{c}{ Enzyme } & $\begin{array}{c}\text { Extent of } \\
\text { buffer }\end{array}$ & $\begin{array}{c}\text { Elumping at 15 } \\
\text { clum of control) } \\
\text { (\%) }\end{array}$ \\
Pancreatin & $7 \cdot 0$ & 27.9 \\
Papain & $4 \cdot 5$ & 0.0 \\
Pepsin & $2 \cdot 3$ & 34.6 \\
Trypsin & $7 \cdot 0$ & 20.9 \\
None (control) & $2 \cdot 3$ & $100 \cdot 0$ \\
& $4 \cdot 5$ & $100 \cdot 0$ \\
7.0 &
\end{tabular}




\section{Clumping of isolated walls of Corynebacterium xerosis NCIB 9956}

Isolated cell walls of Corynebacterium xerosis NCIB 9956 formed clumps when suspensions of the walls in phosphate buffer $(\mathrm{pH} \mathrm{7.0)}$ were incubated at temperatures between of the walls in phosphate buffer ( $\mathrm{pH} 7 \cdot 0)$ were incubated at temperatures between $35^{\circ}$ and $5^{\circ}$ with rapid stirring (Fig. 5). Clumps of walls took $20 \mathrm{~min}$. to rise to the surface of the suspensions in the absorptiometer cells. Pretreatment of the walls with trypsin decreased clumping ability (Fig. 5). Trypsin was preferred to papain as the proteolytic enzyme for digestion since it contained less contaminating material and gave cleaner electron micrographs. The adhesive material that surrounded intact organisms which had been freeze-dried on the electron microscope grid (Pl. 1, fig. 2) could not be seen in electron micrographs of shadowed preparations of freeze-dried walls (P1. 1, fig. 5).

\section{Table 6. Effect of different reagents on the clumping ability of Corynebacterium xerosis NCIB 9956 at $15^{\circ}$}

\begin{tabular}{|c|c|c|}
\hline Reagent & Concentration & $\begin{array}{l}\text { Extent of clump- } \\
\text { ing at } 15^{\circ} \\
(\% \text { of control })\end{array}$ \\
\hline $\begin{array}{l}\text { p-Chloromercuribenzoate } \\
\text { L-Cysteine } \\
\text { Formaldehyde } \\
\text { Guanidine-HCl } \\
\text { 2-Mercaptoethanol } \\
\text { Urea } \\
\text { None (control) }\end{array}$ & $\begin{array}{l}0.01 \mathrm{M} \\
0.20 \%(\mathrm{w} / \mathrm{v}) \\
0.20 \%(\mathrm{w} / \mathrm{v}) \\
5.0 \mathrm{M} \\
0.20 \%(\mathrm{w} / \mathrm{v}) \\
8.0 \mathrm{M} \\
-\end{array}$ & $\begin{array}{l}100 \\
100 \\
100 \\
72 \cdot 5 \\
100 \\
42 \cdot 7 \\
100\end{array}$ \\
\hline
\end{tabular}

\section{DISCUSSION}

Clumping of Corynebacterium xerosis NCIB 9956 in rapidly stirred cultures or suspensions appeared to be caused by a cell-surface or microcapsular component, which became increasingly sticky as the temperature was decreased from $40^{\circ}$ to $5^{\circ}$, causing the organisms which collected around a gas bubble to form a clump. The inability of the bacteria to clump in slowly stirred cultures or suspensions is presumably explained by the absence of large numbers of air bubbles. Electron micrographs of shadowed preparations of bacteria and of thin sections of clumps provided the best evidence for the cell-surface nature of the causative agent. Additional evidence came from the demonstration that suspensions of isolated cell walls formed clumps under the same conditions, although we were unable to show the adhesive material in electron micrographs of shadowed preparations of walls, possibly because the walls were flattened. The electron micrographs of shadowed preparations of bacteria also showed that the adhesive material was distributed over most of the surface of the bacteria. Conceivably, the electron-dense patches seen on the edges of thin sections of bacteria stained with uranyl nitrate represented adhesive material, particularly since uranyl ions, which react specifically with phosphate groups (Rothstein \& Meier, 1951), caused a decrease in the clumping ability. 
Clumping of several different micro-organisms has been shown to be associated with different types of cell-surface component, including carbohydrate (e.g. Sneath \& Lederberg, 1961), protein (Taylor, 1964) and hyaluronic acid (Warren \& Gray, 1955), but the clumping of those organisms has not been reported to be influenced by temperature in the manner found with Corynebacterium xerosis $\mathrm{NCIB} 9956$. The ability of proteolytic enzymes to decrease and even to remove the clumping ability of $C$. xerosis NCIB 9956, together with the inability of lipid solvents or of enzymes and reagents which react specifically with carbohydrates, hyaluronic acid, mucopeptides or sterols, to affect this ability, indicates that a cell-surface protein is involved in the clumping. The presence of protein in corynebacterium walls has been reported by Hewitt (1947) and Cummins (1954), and Stanley (1966) showed that the walls of C. xerosis NCIB 9956 contain about $30 \%$ by weight of protein. Nevertheless, our data do not preclude the possibility that the cell-surface protein on C.xerosis NCIB 9956 is linked to other cell wall or microcapsular components not involved in clump formation. Presumably, those corynebacteria that were unable to clump under the conditions used, and which were present in greatest proportions in early exponential-phase and late stationary-phase cultures, did not have the cell-surface protein or at least not sufficient of it to allow the corynebacteria to clump.

The inhibitory effect of uranyl nitrate on the clumping ability of the corynebacteria suggested that cell-surface phosphate groups were involved in clump formation. The absence of any effect with cysteine, 2-mercaptoethanol (Cecil \& McPhee, 1957), or p-chloromercuribenzoate (Fraenkel-Conrat, 1957), suggested that disulphide bridges and sulphydryl groups did not contribute to the stickiness of the bacteria. Formaldehyde, which reacts with amino and sulphydryl groups in proteins (Fraenkel-Conrat, 1957), also had no effect. Our data indicated, however, that $\alpha$-carboxyl groups may contribute to the stickiness of the cell-surface component, since clumping ability was greatest around $\mathrm{pH} 3$, which is the pK value of the $\alpha$-carboxyl group (Cohn \& Edsell, 1943).

Any hypothesis concerning the mechanism of clump formation in Corynebacterium xerosis NCIB 9956 must include an explanation of the way in which the bacteria aggregate at the gas-bubble/water interface. Since what appears to be the adhesive material can be seen surrounding bacteria that have been freeze-dried on the electron microscope grid, it is evident that the bacteria can become sticky at low temperatures in the absence of gas bubbles. It seems likely that, in liquid cultures or suspensions, gas bubbles provide a suitable interface at which the bacteria can collect. Since only a single layer of bacteria collected round each gas bubble, and substituting nitrogen or oxygen for air as the gas phase had no marked effect on clumping ability, it is conceivable that the collection of bacteria at the gas-bubble/water interface is a 'hydrophobic effect' which might depend upon the presence of exposed hydrophobic amino acid residues in a cell-surface protein (Brandts, 1967). C. xerosis NCIB 9956 and several of the other strains of $C$. xerosis collected in the foam layer when nutrient broth cultures were vigorously aerated (S. O. Stanley and A. H. Rose, unpublished observations). We suggest, therefore, that the ability to collect at the gas-bubble/water interface may not be a result of low-temperature conformational changes in the cell-surface protein, but that clumps were formed only at low temperatures when bacteria which have collected at these interfaces became sticky.

Our data give little information about the nature of the adhesive forces that bind the 
bacteria in the clumps. Since treatment with urea and guanidine- $\mathrm{HCl}$, reagents which are thought to prevent the formation of hydrogen bonds (Kauzmann, 1959), did not completely prevent clump formation, it is possible that other types of secondary bonds in addition to hydrogen bonds are involved. This conclusion may be premature, for Brandts (1967) has stressed how little is know about the effects of urea and guanidine$\mathrm{HCl}$ on hydrogen-bond formation, particularly at low temperatures. The finding that clumps were formed only in the presence of salts suggests that the stickiness may have been caused in part at least by the formation of salt bridges between protein groups on the surfaces of adjacent bacteria.

The limited survey of the clumping ability of coryneform bacteria showed that clump formation, under the conditions used, was confined to species of the genus Corynebacterium. However, not all of the corynebacteria with high minimum temperatures for growth formed clumps at $5^{\circ}$, which suggests that the physiological basis of these high minimum growth temperatures is not directly associated with clumping behaviour. Bacteria are known to aggregate and to adhere to particulate matter in oceans and lake waters at low temperatures. Barber (1966) suggested that the formation of some of these aggregates in sea water involves the deposition of bacteria round air bubbles, possibly, therefore, the aggregation of marine bacteria round air bubbles has a similar physiological basis to that observed in the present study with Corynebacterium xerosis NCIB 9956.

The work reported in this paper was supported by a grant from the Science Research Council (U.K.), for which we are grateful. We are also greatly indebted to Mr E. K. Boult, Mrs Margaret Beck, and Mrs Margaret Iley of the Electron Microscope Laboratory, School of Chemistry, University of Newcastle upon Tyne, for assistance with the electron microscopy. Our thanks are also due to Dr A. L. Davison of the Department of Organic Chemistry, University of Newcastle upon Tyne, for use of the cell homogenizer. One of us (S. O. S.) held a training award from the National Environment Research Council during the course of this work.

\section{REFERENCES}

BARBER, R. T. (1966). Interaction of bubbles and bacteria in the formation of organic aggregates in sea-water. Nature, Lond. $211,257$.

Bergey's Manual of Determinative Bacteriology (1957). 7th ed. Ed. by R. S. Breed, E. G. D. Murray and N. R. Smith, Baltimore: Williams and Wilkins.

BOWER, V. E. \& BATES, R. G. (1955). pH values of the Clark and Lubs buffer solutions at $25^{\circ} \mathrm{C}$. J. Res. Nat. Bur. Stand. 55, 197.

BRADLEY, D. E. \& Williams, D. J. (1957). An electron microscope study of the spores of some species of the genus Bacillus using carbon replicas. J. gen. Microbiol. 17, 75.

BraNDTS, J. F. (1967). Heat effects on proteins and enzymes. In Thermobiology, Ed. by A. H. Rose, p. 25. London: Academic Press.

CECIL, R. \& McPHEE, J. R. (1957). Further studies on the reaction of disulphides with silver nitrate. Biochem. J. 66, 538.

CoHn, E. J. \& Edsell, J. T. (1943). Proteins, Amino Acids, and Peptides as Ions and Dipolar Ions, p. 444. New York: Reinhold Publishing Corporation.

Cummins, C. S. (1954). Some observations on the nature of the antigens in the cell wall of Corynebacterium diphtheriae. Br. J. exp. Path. 35, 166.

FrAENKEL-CoNRAT, H. (1957). Methods for investigating the essential groups for enzyme activity. Meth. Enzymol. 4, 247.

GOMORI, G. (1955). Preparation of buffers for use in enzyme studies. Meth. Enzymol. 1, 138.

HewITT, L. F. (1947). Serological typing of C. diphtheriae. Br. J. exp. Path. 28, 338.

HотснкIss, R.D. (1948). A microchemical reaction resulting in the staining of polysaccharide structures in fixed tissue preparations. Arch. Biochem. 16, 131. 


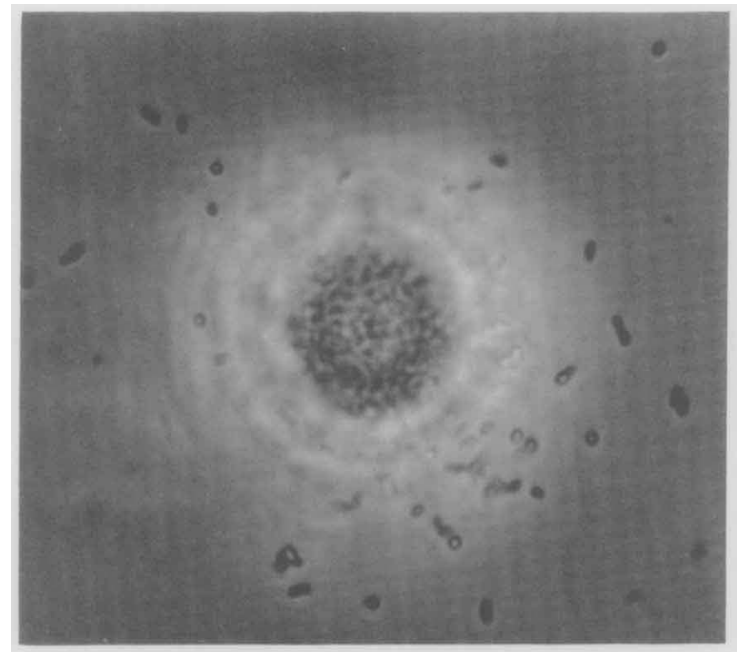

Fig. 1

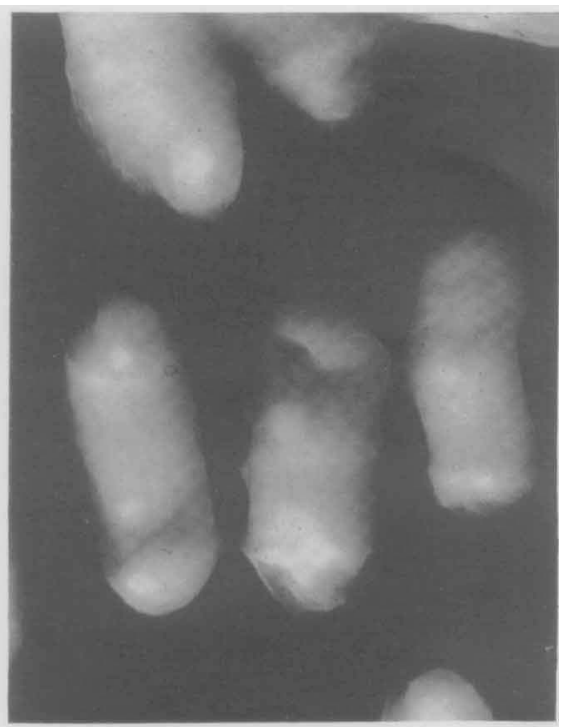

Fig. 2

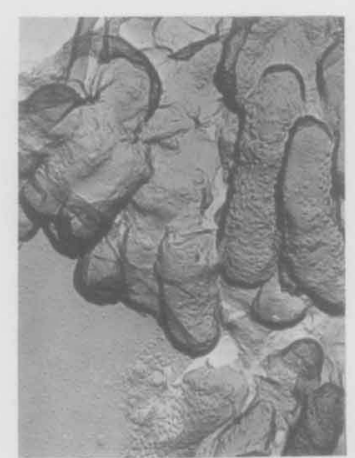

Fig. 3

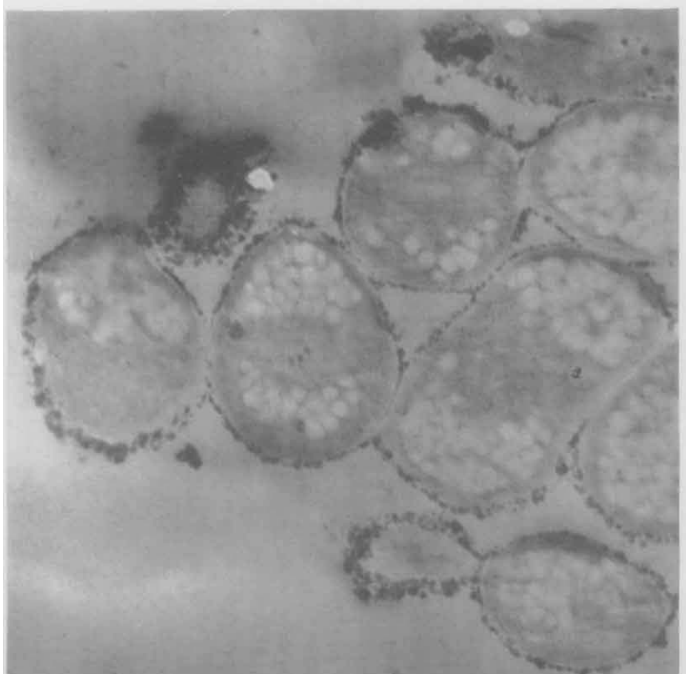

Fig. 5

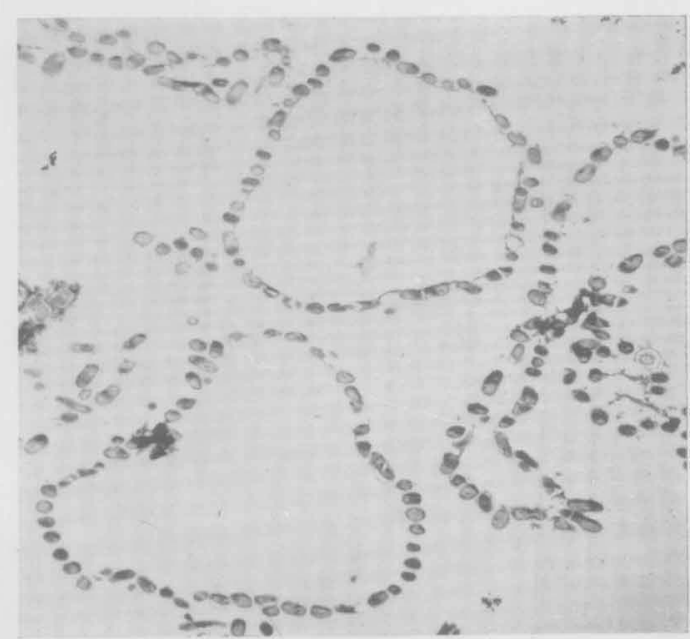

Fig. 4

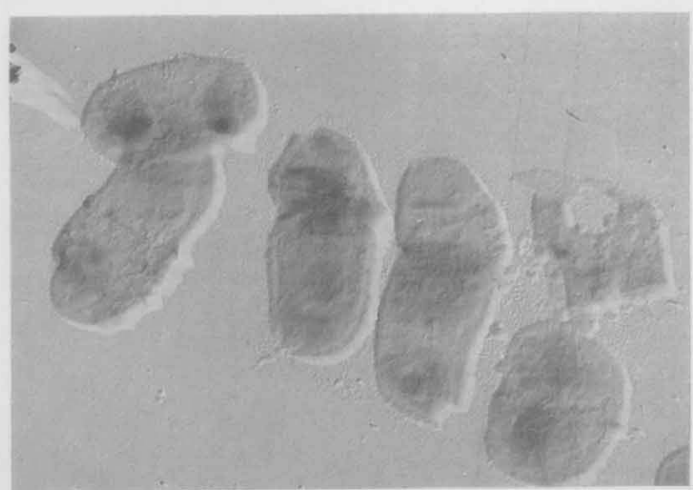

Fig. 6 
Kates, M., Adams, G. A. \& Martin, S. M. (1964). Lipids of Serratia marcescens. Can. J. Biochem. 42, 461.

KAUZMANN, W. (1959). Some factors in the interpretation of protein denaturation. Advanc. protein Chem. 14, 1.

LAMPEN, J. O., ARnow, P. M., BorowsKa, Z. \& LASKIN, A. I. (1962). Location and role of sterol at nystatin-binding sites. J. Bact. 84, 1152.

McIlvaINe, T. C. (1921). A buffer solution for colorimetric comparison. J. biol. Chem. 49, 183.

MerCer, B. H. \& BiRBECK, M. S. C. (1961). Electron Microscopy. Oxford: Blackwells.

NORTHAM, B. E. \& NoRRIs, F. W. (1951). Growth requirements of Schizosaccharomyces octosporus, a yeast exacting towards adenine. J. gen. Microbiol. 5, 502.

Rose, A. H. \& Evison, L. M. (1965). Studies on the biochemical basis of the minimum temperatures for growth of certain psychrophilic and mesophilic micro-organisms. J. gen. Microbiol. 38, 131.

ROTHSTEIN, A. \& MEIER, R. (1951). The relationship of the cell surface to metabolism. VI. The chemical nature of uranium-complexing groups of the cell surface. J. cell. comp. Physiol. 38, 245.

SNEATH, P. H. A. \& LEDERBERG, J. (1961). Inhibition by periodate of mating in Escherichia coli K-12. Proc. nat. Acad. Sci., U.S.A. 47, 86.

StANLEY, S. O. (1966). Studies in low temperature microbiology. Ph.D. thesis: University of Newcastle upon Tyne.

TAYLOR, N. W. (1964). Specific, soluble factor involved in sexual agglutination of the yeast Hansenula wingei. J. Bact. $87,863$.

WALPOLE, G. S. (1914). Hydrogen potentials of mixtures of acetic acid and sodium acetate. J. chem. Soc. 105, 2501.

WARREN, G. H. \& GRAY, J. (1955). Studies on the properties of a polysaccharide constituent produced by Pseudomonas aeruginosa. J. Bact. 70, 152.

YouNG, E. G. (1963). Occurrence, classification, preparation and analysis of proteins. In Comprehensive Biochemistry. Ed. by M. Florkin and E. H. Stotz, vol. 7, p. 1. Amsterdam: Elsevier.

\section{EXPLANATION OF PLATE}

Fig. 1. Photomicrograph of a clump of Corynebacterium xerosis NCIB 9956 from a culture grown at $30^{\circ}$ and cooled to $15^{\circ}$ with fast stirring. $\times 2100$.

Fig. 2. Electron micrograph of Corynebacterium xerosis NCIB 9956, freeze-dried on the electron microscope grid, and shadowed with gold + palladium. $\times 20,000$.

Fig. 3. Carbon replica of Corynebacterium xerosis $\mathrm{NCIB} 9956 . \times 15,500$.

Fig. 4. Electron micrograph of a thin section through a clump of Corynebacterium xerosis NCIB 9956 formed on cooling a culture from 30 to $15^{\circ}$ with fast stirring. $\times 5000$.

Fig. 5. Electron micrograph of a thin section through Corynebacterium xerosis NCIB 9956 stained with uranyl nitrate. The bacteria were clumped by cooling a culture from $30^{\circ}$ to $15^{\circ}$ with fast stirring. $\times 30,300$.

Fig. 6. Electron micrograph of isolated cell walls of Corynebacterium xerosis NCIB 9956, freeze-dried on the electron microscope grid and shadowed with gold + palladium. $\times 20,000$. 